$14^{\text {th }}$ Conf. Agric. Develop. Res., Fac. of Agric., Ain Shams Univ.,

March, 2019, Cairo, Egypt

Special Issue, 27(1), 123 - 134, 2019

Website: http://strategy-plan.asu.edu.eg/AUJASCI/

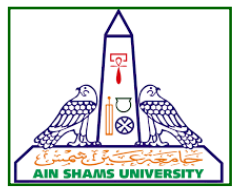

123

\title{
SOLAR HEATING SYSTEM USING PARABOLIC COLLECTOR FOR THER- MAL OPTIMUM CONDITIONS OF BIOGAS PRODUCTION IN WINTER
}

\author{
Sara M. El-Husseini, Mostafa M.M., El-Gindy A.M. and Anwar A.A.
}

[12]

\author{
Agric. Engineering Dept., Fac. of Agric., Ain Shams Univ., P.O. Box 68, Hadyek Shoubra \\ 11241, Cairo, Egypt \\ *Corresponding author: SaraEl-husseini@agr.asu.edu.eg
}

Received 19 February, 2019, $\quad$ Accepted 11 March, 2019

\begin{abstract}
The aim of this study is to enhance the fermentation temperature inside the digester by supplying the required thermal energy to be within the desired optimum range (mesophilic range) for biogas production during winter "cold days". Two $50 \mathrm{~L}$ digesters were used in the experiment that was conducted at Solar Energy Laboratory, Department of Agricultural Engineering, Faculty of Agriculture, Ain Shams University, Cairo. One is a treatment digester and the other is a control digester. The treatment digester is thermally enhanced by a parabolic trough collector, while the control digester operated at the ambient temperature. The experiment was conducted through December 2018 and January 2019. The results show that the average temperature in the control digester through the experiment was $21.5^{\circ} \mathrm{C}$, while in the treatment digester it was $27.08^{\circ} \mathrm{C}$. This means that the parabolic trough collector enhanced the fermentation temperature in the treatment digester by $20.6 \%$. The total biogas yield of the control digester and the treatment digester was $9684.7 \mathrm{~mL} / \mathrm{kg}$. T.S. and $24649.69 \mathrm{~mL} / \mathrm{kg}$. T.S. respectively. By comparing both productivities, it was found that the productivity of the treatment digester was 2.5 times more than the productivity of the control digester.
\end{abstract}

Keywords: Anaerobic digestion, Biogas productivity, Fermentation temperature, solar energy, parabolic trough, heat exchanger, solar tracking, control unit.

\section{INTRODUCTION}

Energy has a notable significance in our life. Despite the technological advances, there are some developing countries that still lack access to a secure energy source. Around 3 billion people from these countries still rely on conventional means to fulfill their energy requirements for cooking. Their basic energy needs are fulfilled by burning biomass resources such as firewood, crop residues, and animal manure. Although this method helps them to meet some of their energy demands, burning biomass and similar practices cause serious environmental, social, economic and public health issues. Thus, to secure their energy needs, it is important to search for another clean, feasible, and renewable energy alternative (Surendra et al 2014).

In spite of the fact that Egypt is on the top of the non-OPEC nations in oil production in Africa and comes in the third place in dry natural gas production, Egypt imports oil products to meet the growing oil demands (EIA, 2018). Many factors had led to this growing energy demand such as population growth, whereas Egypt is the thirdlargest population in Africa (EIA, 2015). In 2016, Egypt came in the first place in oil and natural gas consumption in the continent. It consumed $22 \%$ of oil and other liquids consumption and $37 \%$ of dry natural gas consumption in Africa (EIA, 2018).

Searching for a sustainable energy alternative has become a decisive issue. Among the different renewable energy sources, biogas is a promising alternative for fossil fuel. Anerobic digestion (AD) process generates biogas (Fang, 2010). Also, AD is used as an environmentally friendly technique to manage organic wastes such as animal dung, crop residues, sewage, food processing residues, and others (Dong and Lu, 2013).

The AD process is influenced by different factors such as fermentation temperature, $\mathrm{C} / \mathrm{N}$ ratio, and $\mathrm{pH}$ value. The fermentation temperature af- 
fects both the produced biogas quality and quantity. Thus, it is a critical factor. Biogas can be produced within three wide temperature ranges: psychrophilic (lower than $\left.25^{\circ} \mathrm{C}\right)$, mesophilic $\left(25^{\circ} \mathrm{C}-\right.$ $\left.45^{\circ} \mathrm{C}\right)$, and thermophilic $\left(45^{\circ} \mathrm{C}-70^{\circ} \mathrm{C}\right)$ (Seadi et al 2008). In Egypt, the ambient temperature in winter months is usually between $10^{\circ} \mathrm{C}$ and $20^{\circ} \mathrm{C}$ (weather.com), which is not suitable for biogas production. Not only the low temperature degrees lead to low biogas production rates, but also the fluctuations in fermentation temperature that exceeds $2-3^{\circ} \mathrm{C}$ per hour (Feng et al 2015). In order to guarantee the steadiness of temperature, and also achieve the desired optimal temperature, an external heat source must be used (Alkhamis et al 2000). The thermal energy can be obtained from several sources such as boilers and electric heaters. Also, some of the produced biogas can be used to supply the digester with the required heat. These methods can supply effectively the required temperature, but due to the high energy consumption these methods are not economical (Dong and Lu, 2013). Other alternatives such as solar energy is relatively economical source for heating purposes (Lu et al 2015) especially with the abundance of solar radiation during the entire year in Egypt. Thus, more researches are directed to studying and evaluating the feasibility of using solar energy as an aiding thermal energy source inside the biogas digester.

In this study a parabolic trough collector is used to enhance the fermentation temperature inside the biogas digester to be within the required optimum range (mesophilic range) in winter.

\section{MATERIALS AND METHODS}

The experiment was conducted at Solar Energy Laboratory, Department of Agricultural Engineering, Faculty of Agriculture, Ain Shams University, Egypt, which is located at latitude of $30^{\circ} 06^{\prime} \mathrm{N}$ and longitude of $31^{\circ} 14^{\prime} \mathrm{E}$ from December 2018 to January 2019.

A block diagram for the process is shown in Fig. (1), it consists of three main components: (1) digestion system, (2) parabolic trough collector (PTC), and (3) sun tracking system.

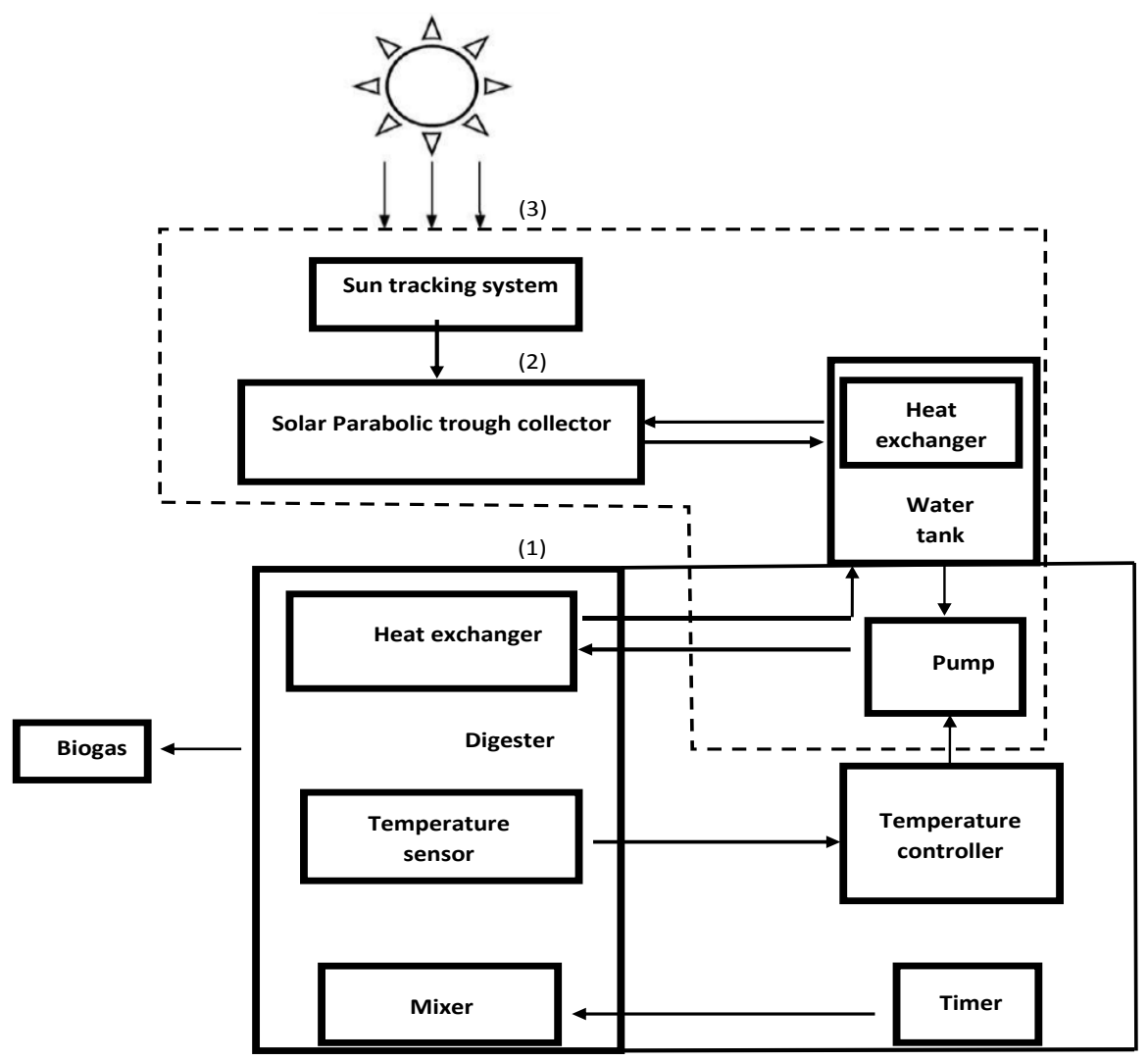

Fig. 1. Block diagram for the system process 


\section{The digestion system}

\subsection{Digesters}

The digestion unit is the essential component of biogas process. Two vertical polyethylene barrels, each one of net volume 50 liters, were turned into experimental biogas digesters. The first digester is the treatment unit with effective volume of 40 liters. It is equipped with heat exchanger, mechanical stirring shaft, and a gas outlet was installed at the cap of the digester. The second digester is the control unit. It is just equipped with the gas outlet tube. The caps of both digesters were sealed into the digesters by using thermal silicon that acts as a gasket to prevent any fluid leakage. Fig. (2) shows the dimensions and a photography picture for the treatment digester.

\subsection{Feedstock}

The used feedstock was cow manure. It is collected from a farm in El-Kanater. The manure was mixed with water in the ratio of $1: 1$ to obtain $10 \%$ total solids (T.S.). The feedstock was added into the digester at the beginning of the experiment in a batch mode.

\subsection{Agitation and Mixing}

The agitation process is carried out by an electrical motor. The motor specifications are as follows: model (Electric Motor Type: 4256R2), power $(12 \mathrm{Hp}), \mathrm{AC}(220 \mathrm{~V})$, frequency $(50 \mathrm{~Hz})$, and rotational speed (35 RPM).

The motor is installed on the top of the treatment digester cap and connected with the stirring shaft. The stirring shaft has three blades of length $100 \mathrm{~mm}$ that are uniformly distributed along the shaft. The blades are soldered on the shaft with 45 - angle. The distance between the digester floor and the stirring shaft is $20 \mathrm{~mm}$. Grease was added to fill the clearance between the stirring shaft and the digester cap.

\subsection{Heat exchanger}

A copper serpentine is installed inside the digester near its wall by clearance of $13.5 \mathrm{~mm}$ from both sides. The number of coils is 9 with diameter of $330 \mathrm{~mm}$.

\subsection{Thermal insulation}

To minimize the thermal losses, a glass wool with $2.5 \mathrm{~mm}$ is used to insulate the digester and the pipes connecting the digester by the pump and parabolic trough.

\subsection{Gas collection and measurement system}

The gas was measured on daily basis via the displacement method at the ambient temperature and atmospheric pressure. Two cylinders are used as the gas collection unit. The first cylinder has a diameter of $152.4 \mathrm{~mm}$ and length of $1500 \mathrm{~mm}$ and closed with a cap from the bottom. It is filled with water. The second cylinder is fitted in the first cylinder. It has the diameter of $101.6 \mathrm{~mm}$ and length of $1300 \mathrm{~mm}$. It is closed with a cap from the upward side and graduated to determine the volume of the produced biogas. The digester is connected to the second cylinder with an $8 \mathrm{~mm}$ flexible plastic hose.

\subsection{The heat balance of the treatment digester}

The heat balance equation for the system (assuming the effluent heat and reaction heat to be negligible (Yuan et al 2011)) can be calculated as follows:

$Q=Q_{w}+Q_{s}$

Where: $Q$ : heat load

$Q_{w}$ : rate of heat transfer to manure

$Q_{s}$ : rate of heat loss through digester walls, floor, and top to the surrounding environment

1.7.1. The heat requirement for the manure:

$Q_{w}=m \cdot C_{p} \cdot \Delta T=m \cdot C_{p}\left(t_{2}-t_{1}\right)$

Where: $m$ : mass of the slurry

$C_{p}$ : the specific heat capacity and approximated for water

$t_{1}$ : the temperature of the slurry

$t_{2}$ : the temperature of fermentation

1.7.2. The heat dissipated to the environment (Yang and Tao, 1998):

a- From the wall of the digester:

$\frac{1}{U_{1}}=\frac{1}{h_{1}} \frac{d_{2}}{d_{1}}+\frac{d_{2}}{2 k_{1}} \ln \frac{d_{2}}{d_{1}}+\frac{d_{3}}{2 k_{2}} \ln \frac{d_{3}}{d_{2}}+\frac{1}{h_{2}}$

Where: $U$ : overall heat transfer coefficient, $\left(\mathrm{W} \mathrm{m}^{-2}\right.$ $\mathrm{K}^{-1}$ );

$h_{1}$ and $h_{2}$ : heat transfer coefficient between manure and the inner wall of the digester, and the outside convection heat transfer coefficient respectively; $\left(\mathrm{W} \mathrm{m}^{-2} \mathrm{k}^{-1}\right)$,

$k_{1}$ and $k_{2}$ : heat conductivity coefficients of the digester and the insulation respectively; $\left(\mathrm{W} \mathrm{m}^{-1} \mathrm{k}^{-}\right.$ $\left.{ }^{1}\right)$, 

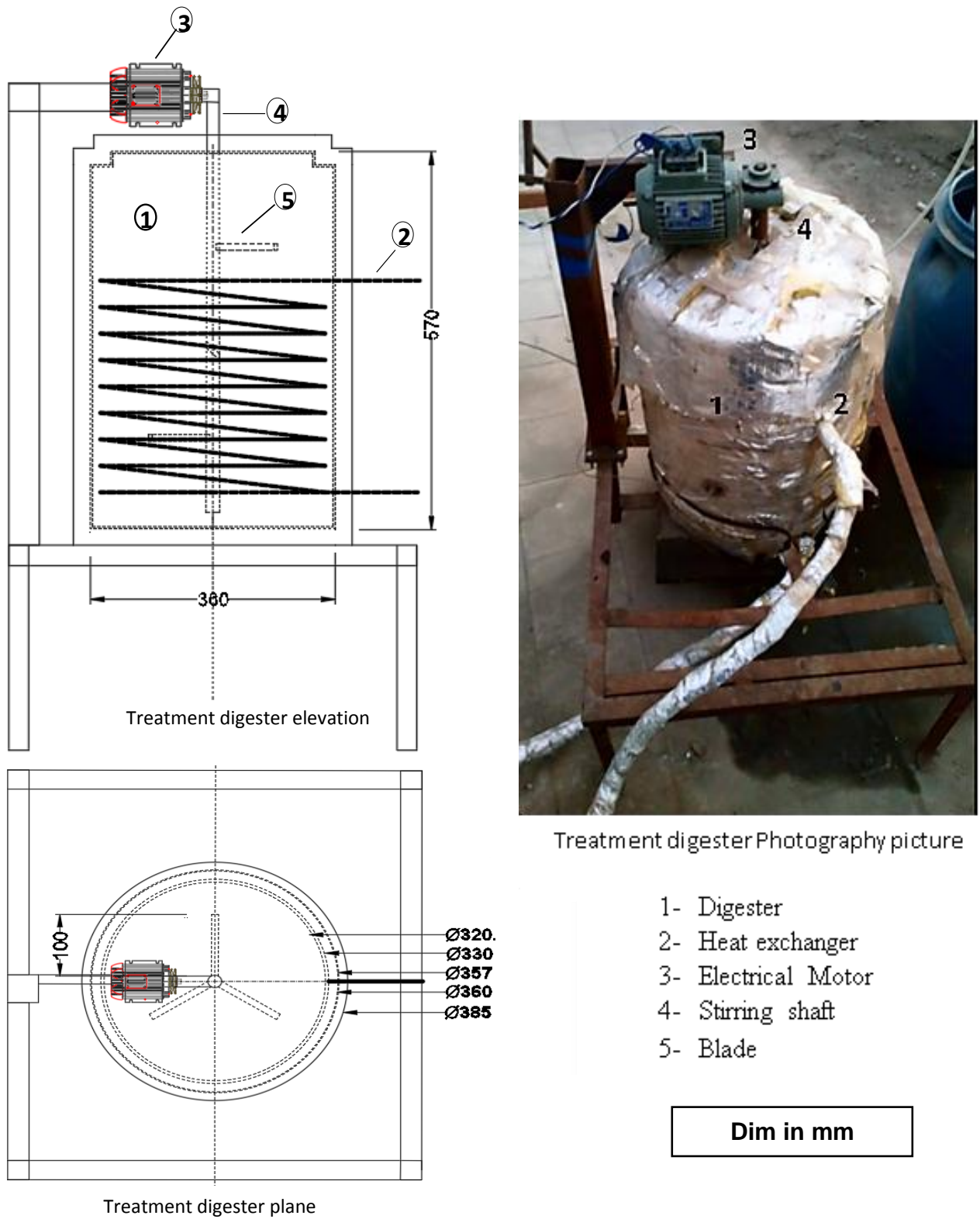

Treatment digester Photography picture

1- Digester

2- Heat exchanger

3- Electrical Motor

4- Stirring shaft

5- Blade

Dim in $\mathrm{mm}$

Fig. 2. Treatment digester dimensions and photography picture 
$d_{1}, d_{2}, d_{3}$ : diameter of each layer; (m).

b- From the top of the digester:

$$
\frac{1}{U_{2}}=\frac{1}{h_{1}}+\frac{L_{1}}{K_{1}}+\frac{L_{2}}{K_{2}}+\frac{1}{h_{2}}
$$

c- From the bottom of the digester:

$$
\frac{1}{U_{3}}=\frac{1}{h_{1}}+\frac{L_{1}}{K_{1}}+\frac{L_{2}}{K_{2}}+\frac{1}{h_{2}}
$$

Where: $L_{1}$ and $L_{2}$ : thicknesses of the digester and insulation respectively; $(\mathrm{m})$.

$$
\begin{aligned}
Q_{s}=U_{1} A_{1}\left(t_{2}-t_{a}\right) & +U_{2} A_{2}\left(t_{2}-t_{a}\right) \\
& +U_{3} A_{3}\left(t_{2}-t_{a}\right)
\end{aligned}
$$

Where: $A_{1}, A_{2}, A_{3}$ : area of the top, sides, and bottom of the digester; $(\mathrm{m})$,

$t_{a}$ : ambient temperature; (K).

\section{Parabolic trough collector (PTC)}

The solar parabolic trough is the used solar concentrator, which is illustrated in Fig. (3). It is made of reflective stainless-steel sheet. It is 1740 $\mathrm{mm}$ long and $1.5 \mathrm{~mm}$ thick. An evacuated tube is located at the focal line.

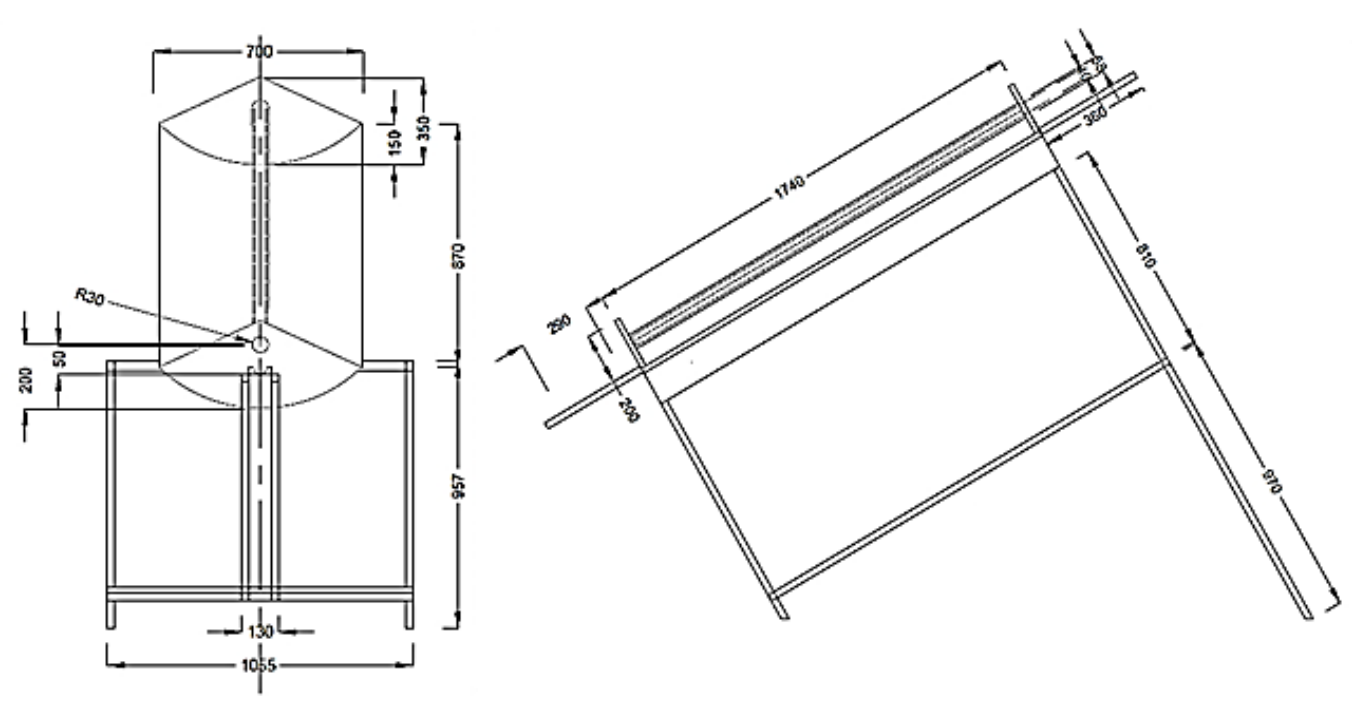

Fig. 3. Parabolic trough collector dimensions

\subsection{Optical analysis of the parabolic trough} (Fig. 4)

The geometrical concentration ratio $\left(C R_{g}\right)$ is calculated as follows:

$C R_{g}=\frac{A_{a}}{A r}=\frac{L\left(D-D_{\text {out }}\right)}{0.5 \pi d_{\text {out }} L}=\frac{D-D_{\text {out }}}{0.5 \pi d_{\text {out }}}$

Where: $A_{a}$ : aperture area, $\left(\mathrm{m}^{2}\right)$;

$A_{r}$ : receiver area, $\left(\mathrm{m}^{2}\right)$;

$D$ : Parabola width, $(\mathrm{m})$;

$L$ : absorber length, $(\mathrm{m})$;

$D_{\text {out }}$ : the outer diameter of the evacuated tube, (m);

$d_{\text {out }}$ : the outer diameter of the serpentine, $(\mathrm{m})$.

The focal length $f$ of the parabola is calculated as follows:

$$
f=\frac{D^{2}}{16 h}
$$

Where: $h$ is the depth of the parabola, $(m)$.

The characteristics of the parabolic trough concentrator are shown in Table (1).

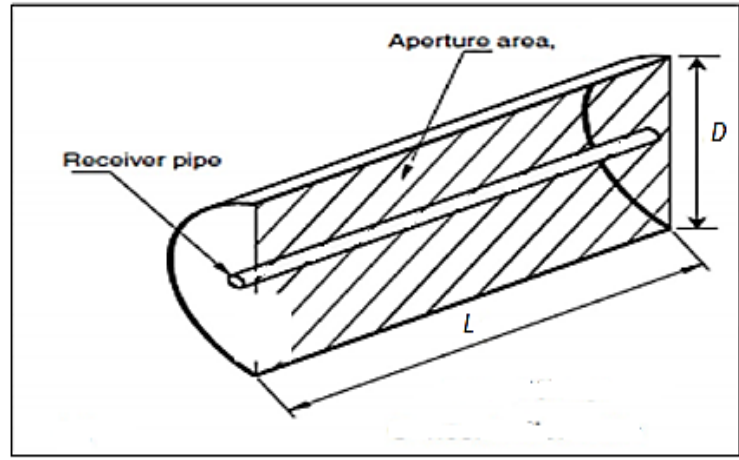

Fig 4. Design parameters of parabolic trough collector (Al Qateimat, 2011).

\subsection{Parabolic trough thermal efficiency (Kalo- girou, 2004)}

The useful energy is calculated as follows:

$Q_{u}=\dot{m} \cdot C_{w} \cdot\left(T_{\text {out }}-T_{\text {in }}\right)$ 
Table 1. Characteristics of the parabolic trough concentrator.

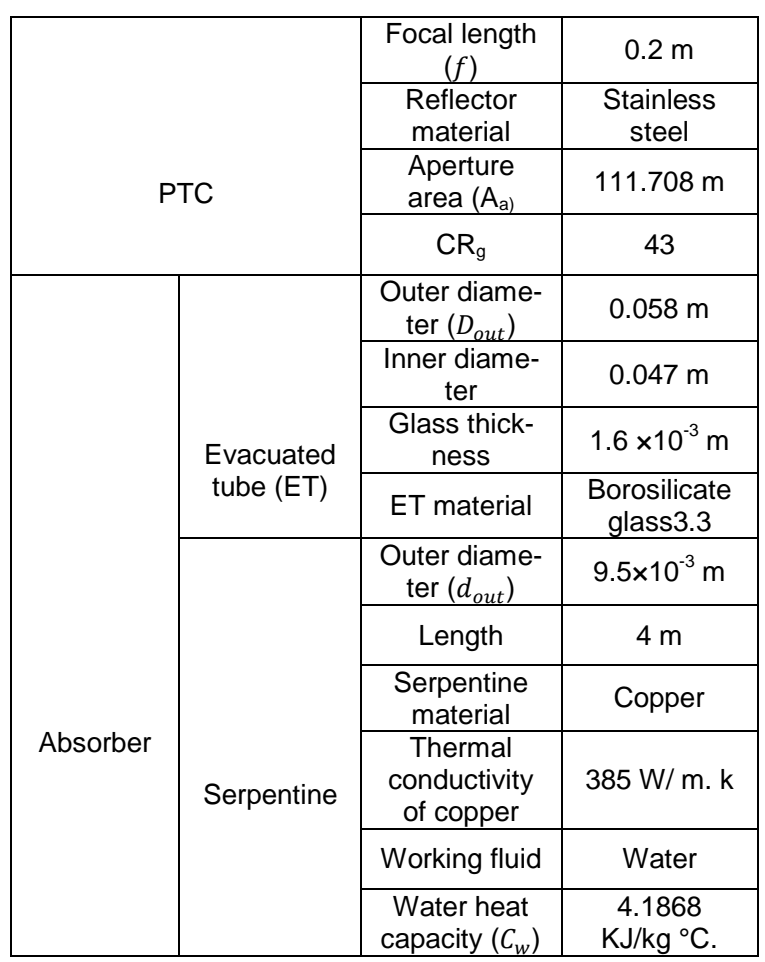

Where: $Q_{u}$ : the useful energy gained in the working fluid, (W);

$\dot{m}$ : mass flow rate of the working fluid, $\left(\mathrm{kg} . \mathrm{s}^{-1}\right)$;

$C_{w}$ : specific heat capacity of the working fluid, (KJ. $\mathrm{Kg}^{-1} \cdot \mathrm{K}^{-1}$ );

$T_{\text {out }}$ : the outlet temperature, $(\mathrm{K})$;

$T_{\text {in }}$ : the inlet temperature, $(\mathrm{K})$.

The solar energy falling on the trough aperture is calculated as follows:

$$
Q_{s}=A_{a} \cdot G_{b}
$$

Where: $Q_{s}$ : received solar energy in the trough aperture, (W);

$A_{a}:$ aperture area, $\left(\mathrm{m}^{-2}\right)$;

$G_{b}$ : incident solar beam radiation on the trough, $\left(\mathrm{W} \mathrm{m}{ }^{-2}\right)$.

The thermal efficiency of the parabolic trough collector $\left(n_{0}\right)$, which is the ratio of the useful heat energy to the solar radiation falling on the trough aperture, is calculated as follows:

$$
\eta_{o}=\frac{Q_{u}}{Q_{s}}
$$

\subsection{Pump and water tank}

The water flows by gravity effect (thermosiphon flow) from the water tank to the copper U- tube inside the evacuated tube which is placed on the focal line of the PTC. After that the solar heated water retain back to the water tank. A centrifugal pump is used to pump the water from the water tank, that is placed on a stand that is higher than the PTC by $500 \mathrm{~mm}$, to the heat exchanger (serpentine) inside the digester. The discharge of the pump was lowered to be between 300-350 L/min by using a feedback connection between the pump and the water tank. The water tank has $237 \mathrm{~mm}$ diameter and $250 \mathrm{~mm}$ height. The pump has the following specifications: model (QB60), maximum discharge (30 L/min), maximum head $(25 \mathrm{~m})$, Volt $(220 \mathrm{~V})$, frequency $(50 \mathrm{~Hz})$, and power $(0.5 \mathrm{Hp})$.

\section{Sun tracking system}

The tracking is essential for solar concentrators to benefit from the greatest amount of solar radiation through the day. The simple tracking system is designed to track the sun in the east-west axis using two light-dependent resistors (LDRs). After tracking the sunlight, a designed circuit gives a signal to two DC motors that have the following specifications: current flow (10 Amp), voltage (24 $\mathrm{V})$, armature resistance $(0.1 \Omega)$, and angular speed (958 radians/s). The two DC motors are fixed on the floor and connected to the two sides of the trough with ropes. The DC motors rotate clockwise or anticlockwise to move the trough in the west or the east direction to follow the sun. Fig. (5) shows a schematic diagram for the sun tracking circuit which is designed according to (Atia et al. 2017). If it is hard to track the sun due to the presence of clouds, the LDR sensor will look for the highest intensity until it reaches it.

The two LDRs are fixed in the middle of the parabolic trough frame (focal line) facing the sun.

\section{Control system}

A control circuit was designed to control the system and switch it on/off. Type $\mathrm{K}$ thermocouple is used to measure the temperature in two points inside the digester. One of them is connected to a temperature controller which gives the signal to stop the pump when the desired temperature reached.

\section{Chemical analysis}

\subsection{Total solids}

Samples of 15.22 grams were dried in electrical oven at $105^{\circ}$ for 24 hours and was weighted with digital balance until reaching equilibrium. The TS\% 


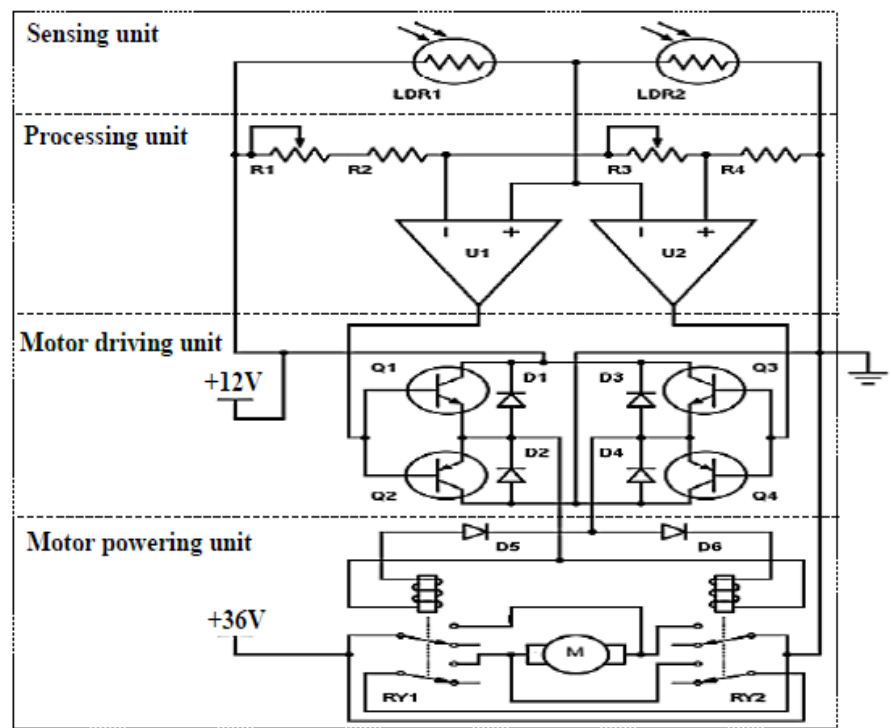

Fig. 5. Schematic of the electronic circuit of sun-tracking system

was calculated from the following formula (APHA, 1999):

$$
T S \%=\frac{M_{T S}}{M_{f}} \times 100
$$

Where: $M_{f}$ : fresh mass; $(\mathrm{kg})$, $M_{T S}$ : mass of total solids; $(\mathrm{kg})$.

\subsection{Organic total solids}

The dried samples that were used to determine the total solids were dried one more time in a muffle oven at $560^{\circ} \mathrm{C}$ and was calculated from the following formula:

$$
\text { OTS } \%=\frac{M_{a s h}-M_{T S}}{M_{f}} \times 100
$$

Where: $M_{a s h}$ is the ash mass; $(\mathrm{kg})$.

The following formula was used to calculate the organic total solids in kilograms:

$$
\text { OTS }=M_{f} \times O T S \%
$$

The characteristics of the cow manure is shown in Table (2).

Table 2. Chemical analysis of cattle dung

\begin{tabular}{|l|l|}
\hline Total solids TS\% & $14.3 \%$ \\
\hline Organic total solids OTS $\%$ & $13.9 \%$ \\
\hline
\end{tabular}

\section{Animal wastes}

The total feedstock that was fed into the digester in batch form was 40 liters including water.
The formula used to calculate the amount of water to be added so that to reach the desired TS\% is:

$$
Y=x\left(\frac{T_{s 1}-T_{s 2}}{T_{s 2}}\right)
$$

Where:

Y: dilution volume, (liter);

$\mathrm{X}$ : amount of raw material added, $(\mathrm{kg})$;

Ts1: total solid of raw material;

Ts2: total solid of fermentation material.

\section{RESULTS AND DISCUSSION}

This study was about utilizing solar energy in providing biogas digester with the desired temperature in the mesophilic range. The heat gained from the PTC enhanced the performance of the anaerobic bacteria. The used solar energy technique was a PTC with an evacuated tube. The experiment included two digesters, the treatment digester which was thermally enhanced by PTC, and the control digester which was without any thermal enhancement. The two digesters were set-up in the same climatic conditions. The results of biogas productivity for the two digesters were compared.

\section{The thermal performance}

Fig. (6) illustrates the variation of the parameters; solar radiation and absorber temperature as function of time using sun- tracking mechanism. The experiment started from 8 am till $4 \mathrm{pm}$. Average solar radiation ranged from $36.6 \mathrm{~W} / \mathrm{m}^{2}$ to 766.6 $\mathrm{W} / \mathrm{m}^{2}$ through the day. The solar radiation reached its peak at $12 \mathrm{pm}$. The temperature at the outlet of 


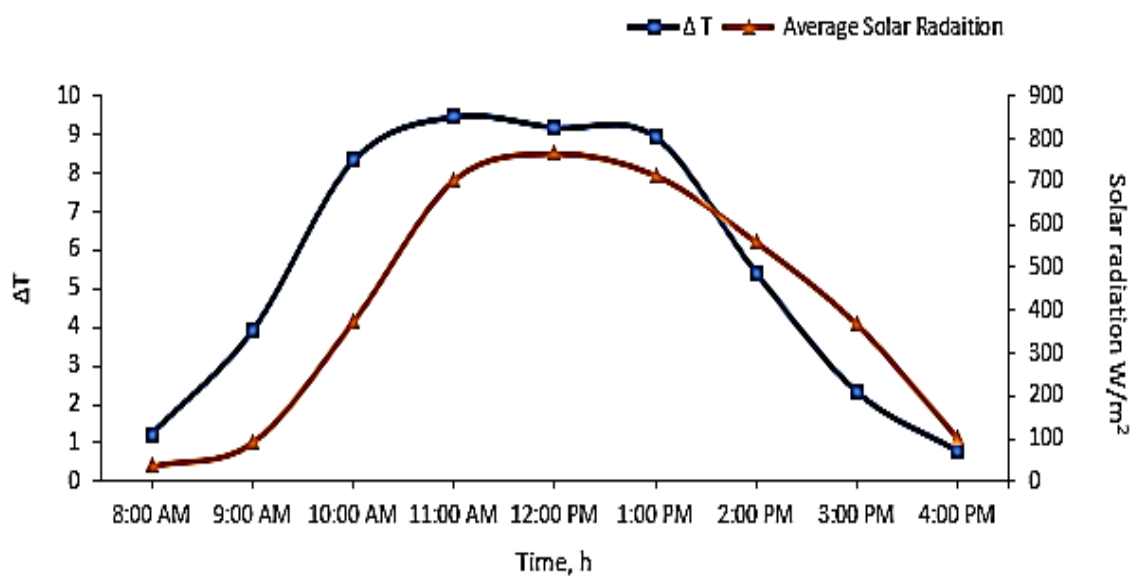

Fig. 6. The water temperature variation in the absorber.

the absorber increased due to the concentration of solar radiation on the absorber. The variation in the water temperature in the absorber reached its peak from 10 am to $1 \mathrm{pm}$.

Fig. (7) shows the average hourly temperatures during the experiment for both digesters. The control digester is affected by ambient temperature, wind speed, and solar radiation. The treatment digester is thermally insulated, and its temperature is affected by the heat exchange process between the water heated by PTC and manure. The maximum average temperature reached in the control digester was about $24.5^{\circ} \mathrm{C}$ from 1 pm until $2 \mathrm{pm}$, while the maximum average temperature reached in the treatment digester was $32.2^{\circ} \mathrm{C}$ at 1 $\mathrm{pm}$. It's obvious from the graph that the average fermentation temperature of the control digester is greatly affected by the average ambient temperature whereas the values for both of them are so close.

The solar heating system increases the temperature inside the digester by $20.6 \%$. The temperature starts to decrease in both digesters after $2 \mathrm{pm}$.

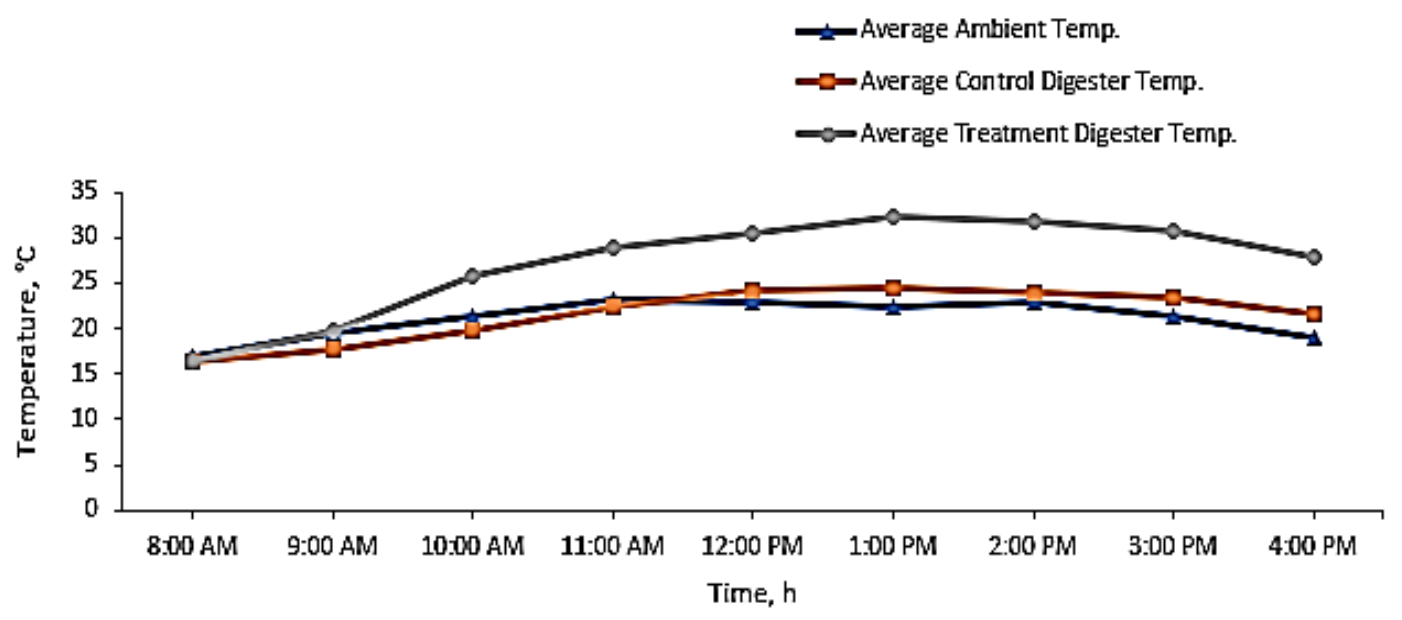

Fig. 7. Comparison of the average hourly temperatures between the control and treatment digesters throughout the experiment 


\section{Solar heating system using parabolic collector for thermal optimum conditions of biogas production in winter}

\section{Daily biogas production rate}

The rate of biogas production for the treatment digester and control digester is illustrated in Fig. (8) throughout the experiment. Also, the graph shows the effect of the fermentation temperature on the biogas productivity. The average fermentation temperature in the treatment digester is higher due to the supplied thermal energy from the PTC. Through the productive days of the experiment the average ambient temperature was about $21^{\circ} \mathrm{C}$.

The first day for biogas collection started after the six days of the experiment, whereas there wasn't any significant productivity in the first six days. The biogas productivity increases with the increase of the fermentation temperature. The quantity of biogas produced from the treatment digester is apparently greater than the control digester, whereas the PTC could keep the fermentation temperature within the proper range most of the time. Therefore, treatment process could be performed more effectively. Also, it's obvious from the graph that the fermentation temperature impacts the productivity greatly. The maximum productivity for the control digester was $939.5 \mathrm{~mL} /$ $\mathrm{kg}$. T.S. and for the treatment digester was 1910.8 $\mathrm{mL} / \mathrm{kg}$. T.S.

\section{Accumulated productivity}

Fig. (9) shows a comparison between the accumulative biogas production of both treatment and control digesters. The accumulative productivity of the control digester was $9684.7 \mathrm{~mL} / \mathrm{kg}$. T.S, and the accumulative productivity of the treatment digester was $24649.69 \mathrm{~mL} / \mathrm{kg}$. T.S. This means that the accumulative productivity of the treatment digester is higher by about 2.5 times than that of the control digester.

\section{Thermal system performance}

Fig. (10) shows the average overall thermal efficiency in the effective period from 8 am until $1 \mathrm{pm}$ for 15 days of the experiment. The average solar radiation was $451.5 \mathrm{~W} / \mathrm{m}^{2}$. The daily average useful heat that was gained by the manure was 740.9 Wh.

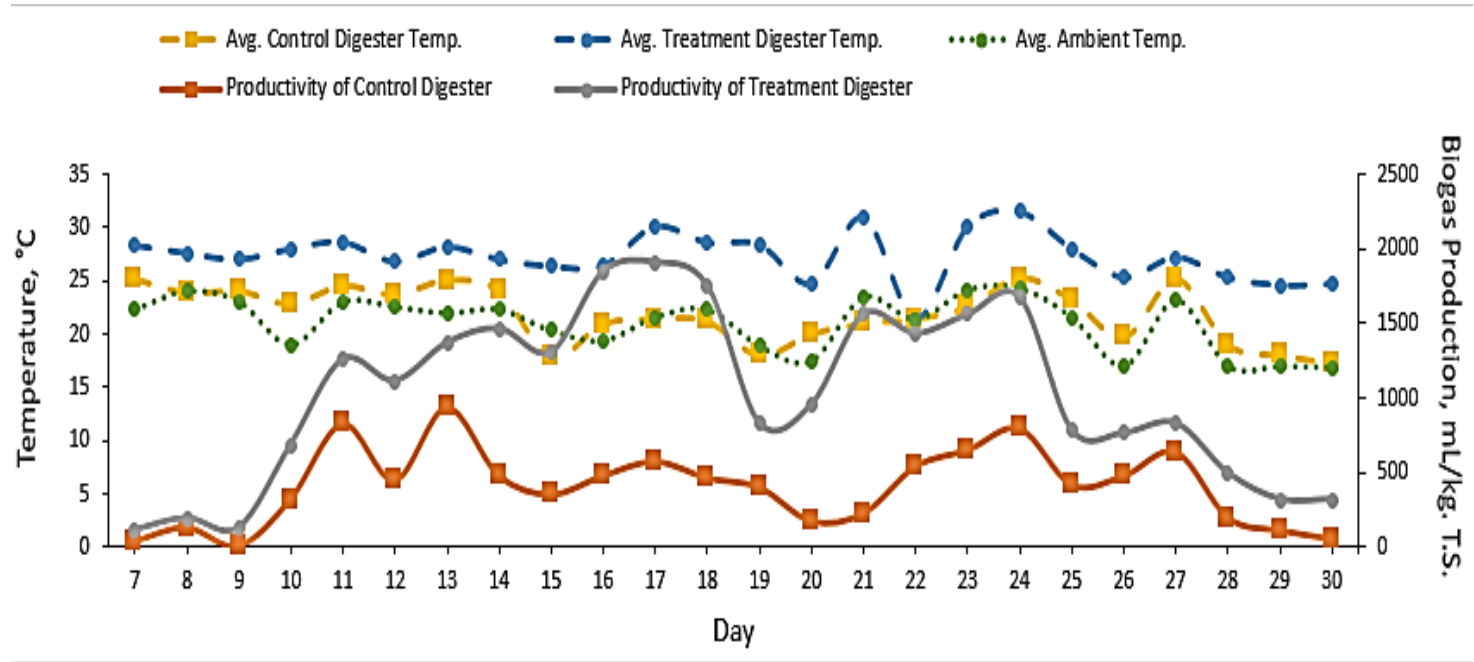

Fig. 8. The relation between the biogas productivity of the control digester and the treatment digester and the fermentation temperature of both digesters. 


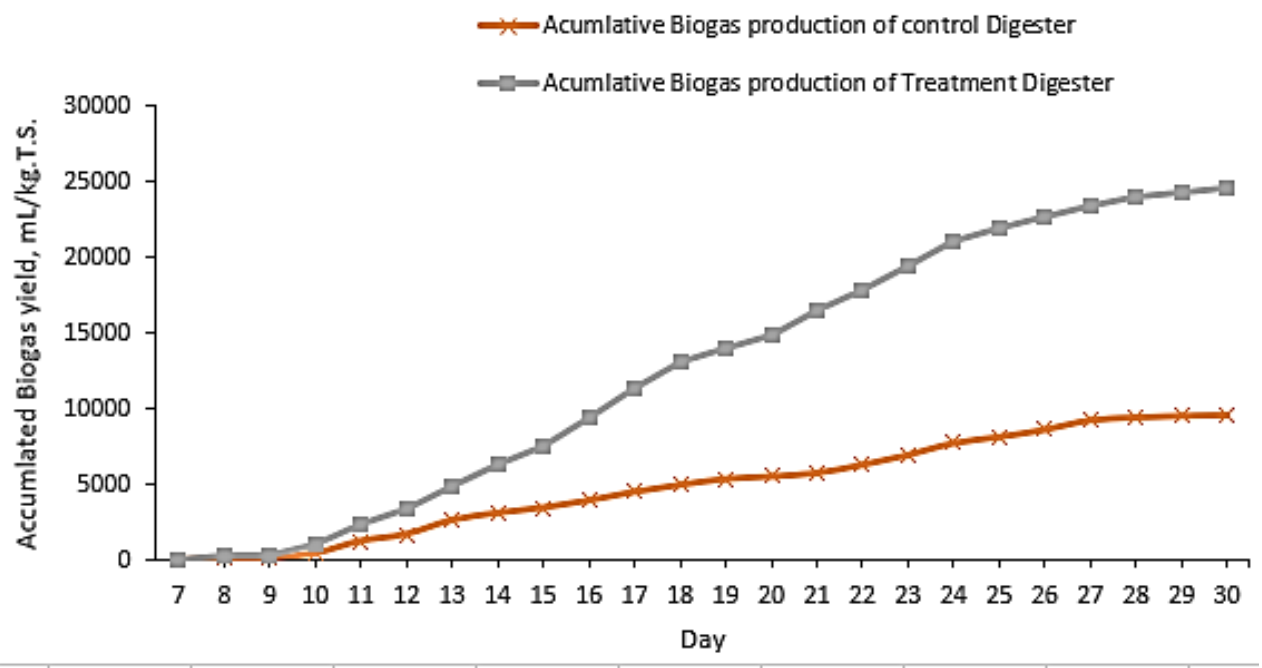

Fig. 9. Quantities of accumulated biogas production for control and treatment digesters

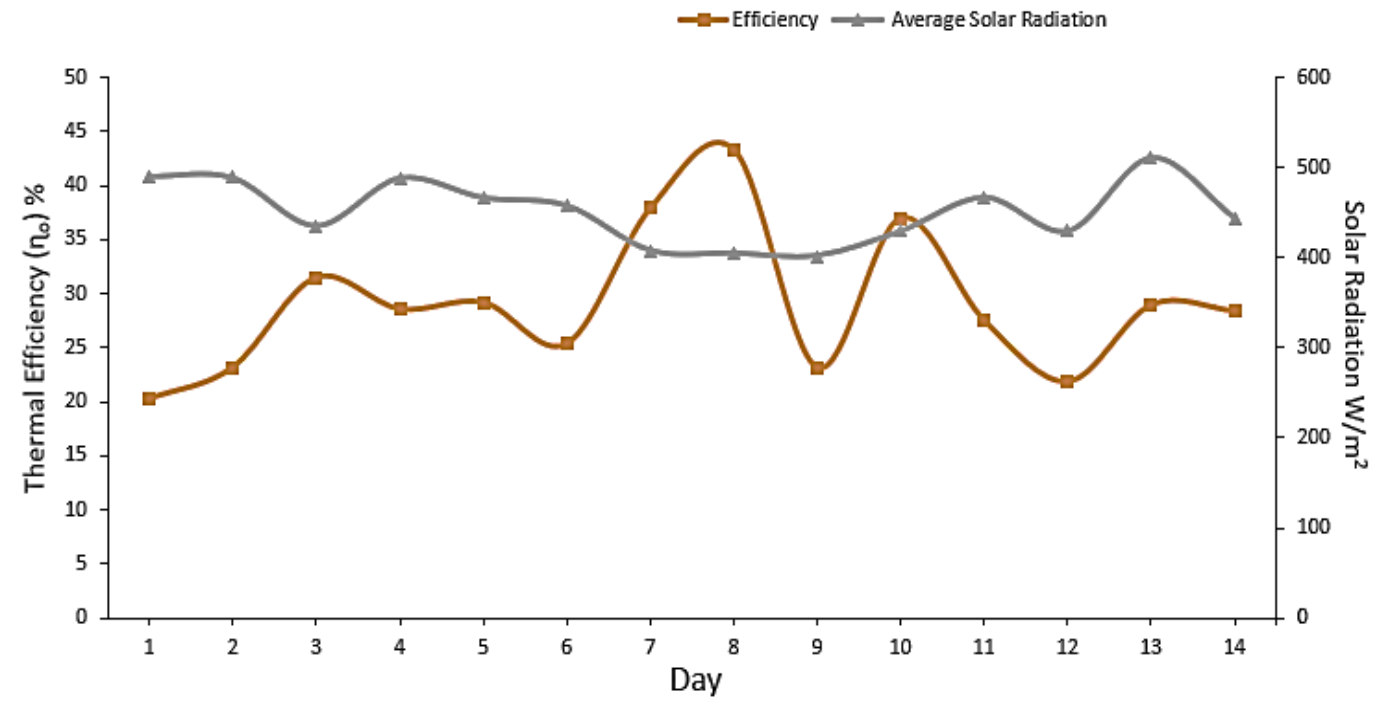

Fig. 10. The system overall thermal efficiency

It is clear that the lowest thermal efficiency during a day was $20.3 \%$, while the highest thermal efficiency value was $43.3 \%$.

\section{CONCLUSION}

Using solar energy collector of area 1.11708 $\mathrm{m}^{2}$ increased the fermentation temperature inside the treatment digester through a heat transfer process. This technique almost maintained the digester fermentation temperature within the mesophilic range and increased the temperature inside the digester by $20.6 \%$. Also, this technique increased the biogas productivity, whereas the treatment digester produced $24649.69 \mathrm{~mL} / \mathrm{kg}$. T.S which is 2.5 times higher more than the control digester productivity which was $9684.7 \mathrm{~mL} / \mathrm{kg}$. T.S.

\section{RECOMMENDATIONS}

It can be recommended that:

1- Use another source for heat energy such as; electrical heater to maintain the optimum temperature continuously without fluctuations in cloudy and partly cloudy days of winter. 
2- Perform an economic analysis for the system and compare it with the other alternatives from the solar collectors.

\section{REFERENCES}

Alkhamis, T. M., El-Khazali R., Kablan M.M. and Alhusein M.A. 2000. Heating of a biogas reactor using a solar energy system with temperature control unit. Solar Energy, 69 (3), 239247.

Al Qteimat, A.M. 2011. Modeling and analysis of the performance of a parabolic trough solar concentrator, M.Sc. Thesis, Jordan Univ., Jordan, pp. 28-29.

APHA, 1999. Standard Methods for the Examination of Water and Wastewater. American Public Health Association, American Water Works Association, Water Environment Federation, Washington, D.C, USA, pp. 226-227

Atia, M.F., Mostafa M.M., El-Nono M.A. and Abdel-Salam M.F. 2017. Milk pasteurization using solar concentrator with tracking device. Misr J. Ag. Eng., 25 (4), 1438-1453.

Dong, F. and Lu J. 2013. Using solar energy to enhance biogas production from livestock residue- A case study of the Tongren biogas engineering pig farm in South China. Energy, 57, 759-765.

EIA, 2015. U.S. Energy Information Administration. Country Analysis Brief: Egypt, Washington, D.C, USA, pp. 1-10.

EIA, 2018. U.S. Energy Information Administration. Country Analysis Brief: Egypt, Washington, D.C, USA, 1 p.
Fang, C. 2010. Biogas production from foodprocessing industrial wastes by anaerobic digestion. Ph.D. Thesis, Dept. of Env. Eng., Tech. Univ. of Denmark, Kgs. Lyngby, Denmark $41 \mathrm{p}$.

Feng, R., Li J., Dong T. and Li X. 2015. Performance of a novel household solar heating thermostatic biogas system. Applied Thermal Engineering, 96, 519-526.

Kalogirou, S.A. 2004. Solar thermal collectors and applications, Progress in Energy and Combustion Science, 30, 231-295.

Lu, Y., Tian Y., Lu H., Wu L. and Li X. 2015. Study of solar heated biogas fermentation system with a phase change thermal storage device. Applied Thermal Engineering, 88, 418-424.

Seadi, T.A., Rutz D., Prassl H., Köttner M., Finsterwalder T., Volk S. and Janssen R. 2008. Biogas Handbook, $1^{\text {st }}$ Ed. Univ. of Southern Denmark Esbjerg, Esbjerg, Denemark, $23 \mathbf{p}$.

Surendra, K.C., Takara D., Hashimoto A. G. and Khanal S.K. 2014. Biogas as a sustainable energy source for developing countries: Opportunities and challenges. Renewable and Sustainable Energy Reviews, 31, 846-859.

Weather website: https://weather.com/arEG/weather/monthly/I/EGXX0004:1:EG.

Yang, S.M. and Tao W.Q. 1998. Heat Transfer, $3^{\text {rd }}$ Ed., Higher Education Press, Beijing, China pp. 207-212.

Yuan, S., Rui T. and Hong Y.X. 2011. Research and analysis of solar heating biogas fermentation system. Procedia Environmental Sciences, 11, 1386-1391. 



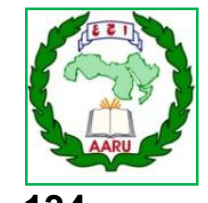

المؤتمر الرابع عشر لبحوث التتمية الزراعية،

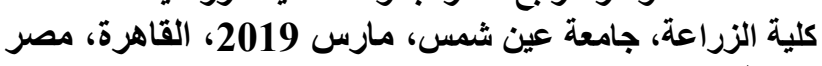

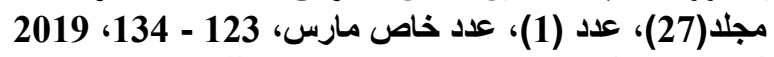

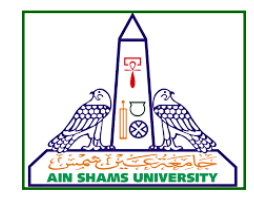

نظام تسخين شمسى بإستخدام مجمع مركز للحصول على الظروف الحرارية المثالية لإنتاج البيوجاز فى الشتاء

[12]

سارة محمد الحسيني- مبارك محمد مصطقى - عبدالغني محمد الجندي- أشرف عبدالجليل أنور

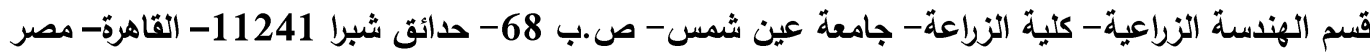

"Corresponding author: SaraEl-husseini@agr.asu.edu.eg .

Received 19 February, 2019, Accepted 11 March, 2019

درجة الحرارة فى المخمر التجريبى خلال التجربة كان

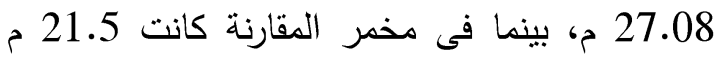
مما يعنى ان اللهمع قد حسن درجة الحرارة داخل

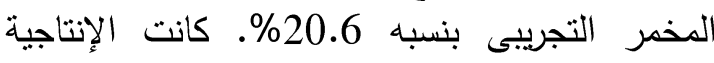

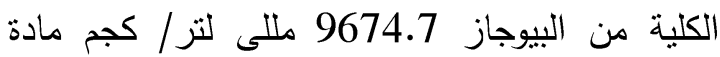

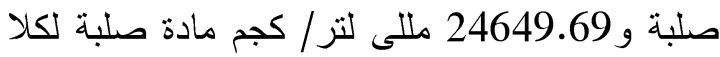

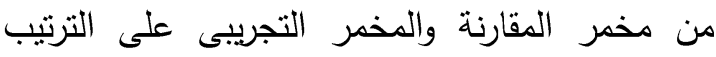
بمعدل زيادة مقداره 2.5 مرة.

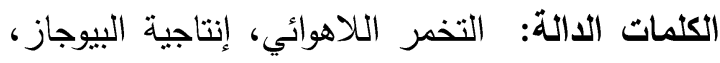

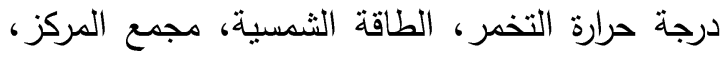
مبادل حراري، التتبع الثمسي، وحدة التحكم لطئ

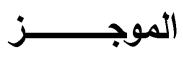

تهدف هذه الدراسة الى تحسين درجة الحرارة داخل

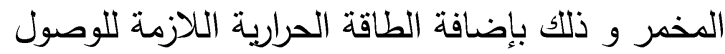
الى المدى الأمثل لدرجات الحرارة لإنتاج البيوجاز

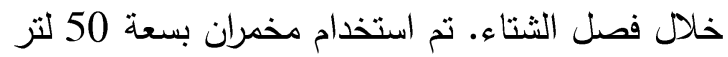

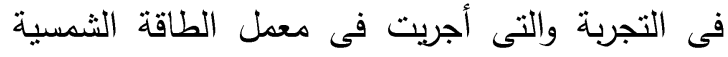

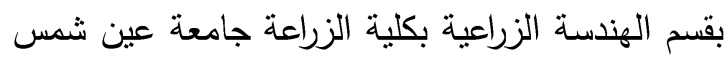

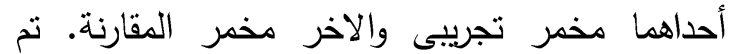
تحسين الظروف الحرارية للمخمر التجريبى باستخدام

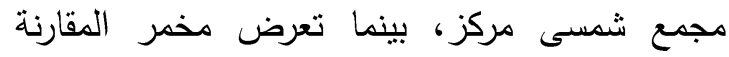
للظروف الجوية. أجريت التجربة خلال شهرى ديسم ديسمبر

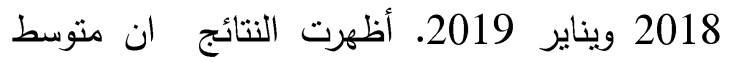

